\title{
DAUVERGNE, Catherine. - The New Politics of Immigration and the End of Settler Societies
}

\author{
Ekpedeme Edem
}

\section{(2) OpenEdition}

Journals

Electronic version

URL: https://journals.openedition.org/etudesafricaines/22017

DOI: 10.4000/etudesafricaines.22017

ISSN: $1777-5353$

\section{Publisher}

Éditions de l'EHESS

\section{Printed version}

Date of publication: 15 March 2018

Number of pages: $241-244$

ISBN: $978-2-7132-2741-7$

ISSN: 0008-0055

\section{Electronic reference}

Ekpedeme Edem, "DAuvergne, Catherine. - The New Politics of Immigration and the End of Settler Societies", Cahiers d'études africaines [Online], 229 | 2018, Online since 15 March 2018, connection on 22 April 2022. URL: http://journals.openedition.org/etudesafricaines/22017 ; DOI: https://doi.org/ 10.4000/etudesafricaines.22017

This text was automatically generated on 22 April 2022.

(c) Cahiers d'Études africaines 


\title{
DAUVERGNE, Catherine. - The New Politics of Immigration and the End of Settler Societies
}

\author{
Ekpedeme Edem
}

\section{REFERENCES}

DAUVERGNE, Catherine. - The New Politics of Immigration and the End of Settler Societies.

Cambridge, Cambridge University Press, 2016, 288 p., bibl., index.

1 This review of Catherine Dauvergne's The New Politics of Immigration and the End of Settler Society summarizes the contribution of the book to the changing global migration landscape. The review outlines the three shifts observed by Dauvergne in the new politics of immigration in a post-post-colonial era. There is a tie-in between Dauvergne's thoughts on the impact of the fear of Islamic fundamentalism connected to immigration politics and the Trump administration's evolving stance on immigration. Dauvergne's foresight is commendable.

2 C. Dauvergne is Professor of Law and Dean of the Peter A. Allard School of Law at the University of British Columbia in Canada. As a fellow of the Pierre Elliot Trudeau Foundation, her research work broadly covers globalisation, refugee, immigration, citizenship law and policies in Canada and the world. Some of Dauvergne's previous works include Making People Illegal: What Globalization Means for Migration and Law and Immigration Law in Canada-Cases and Materials.

3 This book, The New Politics of Immigration and the End of Settler Society, speaks to policy makers, scholars, refugee advocates, the judiciary, national governments, and the international community. The case studies utilised are drawn from "settler societies," namely in the United States of America, Canada, Australia and New Zealand. Dauvergne asserts that these countries have a strong settler society immigration history and 
hitherto strong settler society ethos for migrants. Nations which were built through considerable migration also set the pace in migration regulation (p. 4).

Dauvergne suggests there is a change in immigration regimes in "settler" countries, culminating in an alignment of migration policies worldwide. She argues that though global in application, the change is driven by Western democracies (p. 1). Dauvergne identifies a new model of immigration law and policy. This new model is referred to as "a mean-spirited politics of immigration" (p.2). Western states have and are undergoing a hard-line immigration remodelling. This new politics of immigration is not yet cast in stone, but rather is still emerging in response to global issues.

Dauvergne points out that the new politics of immigration is a combination of past and present events, economics of migration and human rights discourse, among other factors. She characterises it as a type of immigration politics that defies definition (p. xi) and produces "policy paralysis» (p. 2). Dauvergne suggests that immigration policies are not only steeped in politics, but that the issue of immigration itself has grown to become the focus of politics. Western democracies are paying more attention to refugees and the enduring asylum crisis ( $\mathrm{p} . \mathrm{x}$ ) and, at present, immigration is on the agenda in every election in North America, Europe and their antipodes (p.1). Immigration is political. Dauvergne indicates that this new politics of immigration is heralded by the demise of settler societies as an immigration paradigm (p. 2).

Three non-mutually exclusive shifts are identified in the book as stages in the transition of immigration politics. First, the change is connected to the global asylum crisis. Dauvergne points out that the persistent nature and increase in number of asylum seekers exceed the resources of Western states, resulting in significant changes to immigration politics with global alignments. Regrettably, these changes have eroded the line between asylum and illegal migration.

7 Second is the fear of Islamic fundamentalism. Dauvergne states that this fear is resulting in increased securitization of immigration and islamophobia, as evidenced by the increased use of technology for screening purposes at airports. In chapter 4, Dauvergne traces the events accentuating the rise of islamophobia since the 9/11 attacks. She analyses how the fear of Islamic fundamentalism has led to increased police and military control of migration and a spike in anti-immigrant sentiments. In an interesting twist, Dauvergne highlights the paradox of the fact that these "meanspirited" changes thrive under liberalism; illiberalism, neo-conservativist campaigns, such as "the war on terror" and the massive detention of immigrants, to mention a few, is encouraged under the cloak of liberalism.

8 The third change identified by Dauvergne is the demise of multiculturalism, which she says marks the end of an "ideological paradigm" for immigration. In Chapter 5, Dauvergne expounds on the loss of the ideological function of multiculturalism by asserting that while most societies are still referred to as multicultural, the paradigm has lost its function and political relevance in the identified "settler states." This loss is not unrelated to the asylum crisis and fear of Islamic fundamentalism. The chapter goes further to address objections to the notion that multiculturalism has met its Waterloo.

9 Dauvergne indicates that the book adopts a "big picture" approach, which takes into consideration past and present migration events. Put differently, a consideration of significant landmark events in immigration history is essential for understanding immigration politics over time. The aim is to provide a comprehensive overview of the 
past and present, with a view to charting a course for future regulation of immigration. A knowledge of the past as it leads up to the present is useful, however, the past must be left as just that (p. xi). Emphasis is not placed on a detailed analysis of current immigration policies but rather on a narrative history, telling the story of when, where, what, how and why the changes in immigration politics occur. Chapters 1-2 introduce the reader to the book with a history of the immigration landscape of the identified settler societies. Chapters 3-5 deal with the "why," i.e., the factors leading to the change in politics of immigration. Chapters 6-10 are focused on putting the new politics into context. Dauvergne asserts here that immigration considerations extend beyond human rights discourse and economic gains of migration. Dauvergne, in this section, draws upon a narrative which links the past to the present, with a goal of conceptualising a possible future for regulating immigration.

Dauvergne hopes the book will serve as a tool for navigating the changing terrain of refugee politics in the twenty-first century and lead to a new direction in global immigration politics (p. xii). This book was published in 2016 at the height of the Syrian refugee crisis, increased fatalities of African migrants attempting to reach Europe by sea, and a record high of displaced persons globally whilst in the midst of growing coverage of the activities of Islamic fundamentalists, such as ISIS, in the media. These have resulted in fierce opposition to asylum and the spread of anti-immigrant sentiments, despite increased national conflicts displacing an unprecedented number of people. I am inclined to agree with Dauvergne's hint that the media plays a role in immigration politics. Scholars have noted that the media "conditions public opinion and the policy landscape." ${ }^{1}$

11 Situated within the "post-post-colonial discourse," Dauvergne conceptualises this discourse as one in which immigrants are broadly categorised into two groups, namely the "sought-after highly mobile" and the "illegal" (p. 8). Whereas the economics of migration and human right discourses play a significant role, they are insufficient bases for a thorough analysis of this new regime. Dauvergne conceptualises the new politics of immigration as a movement beyond colonization and decolonization (p.5) that cannot fully be addressed within post-colonial concepts such as decolonisation (p. 11) even though these concepts can provide support for European citizenship (p. 8).

Dauvergne's narrative cuts across several ideas: immigration and citizenship; crimmigation; the legal status of migrants and the right to stay; racial profiling and immigration; refugee and asylum discourse; economic migration; and law and immigration. Reference is made to a wide array of sources including books, articles, reports, papers, media sources, case law, treaties and legislation. The book's appendices include tables, graphs and information on census questions reflecting data on ethnicity, refugee settlement, asylum seeking, Muslim immigration, overall migration to the paradigmatic settler states (and selected comparators), temporary worker migration, illegal migration, European migration and deportation.

13 This book is timely as it examines present-day immigration realities evolving globally and spearheaded by Western liberal democracies. Dauvergne asserts that "the new politics of immigration is characterized by legalization, rapid change, defiance of partisan expectations, a new worldwide 'us' and 'them' divide, existential fear, and an unprecedented place on the central political stage of all Western liberal democracies" (p. 8). At no point in time has this assertion been truer than with the Trump era, 
marked by a derogation from the settler society ethos, an embodiment of the illiberality of liberalism and the uncertainty of certainty.

Dauvergne's New Politics of Immigration and the End of Settler Society is a must-read for a base understanding of current immigration trends. Although it does not specify the way forward, the book provides a launching pad for re-imagining immigration in the twenty-first century.

\section{NOTES}

1. B. AKDENIZLI, JR., E. J. DIONNE, M. KAPLAN, T. ROSENSTIEL \& R. SURO (eds.), Report on the Media and the Immigration Debate. Democracy in the Age of New Media, Los Angeles, Norman Lear Center; Washington, DC-Brookings Institute (“Governance Studies”), 2008, p. vi. 